\title{
O Devoto e a Santa: o círio de Nossa Senhora das Graças numa comunidade quilombola paraense
}

\author{
Donizete Rodrigues ${ }^{\mathrm{a}}$ \\ Ingrid Heinen $^{\mathrm{b}}$
}

Baseado, principalmente, na construção teórica-conceptual durkheimiana, este artigo tem como objetivo abordar a romaria em homenagem à Nossa Senhora das Graças, que ocorre no mês de novembro, na comunidade quilombola paraense da Vila do Cravo. Seguindo a orientação metodológica geertziana, o trabalho de campo foi realizado utilizando a observação-participante, com uma densa etnografia, envolvendo símbolos, rituais e experiências profanas e do sagrado, vividas no contexto da comunidade. Esta romaria, como prática religiosa popular, possibilita trocas culturais, (re)encontros e o fortalecimento dos vínculos sociais entre os romeiros.

Etnografia, Círio, Romaria, Nossa Senhora das Graças, Vila do Cravo/Pará.

Com base, principalmente, na construção teórica-conceptual durkheimiana, este artigo tem como objetivo abordar as práticas e experiências festivas religiosas que compõem o Círio e, de maneira mais específica, a romaria em homenagem à Nossa Senhora das Graças, que ocorre no mês de novembro na comunidade quilombola paraense da Vila do Cravo.

a Professor Associado com Agregação da Universidade da Beira Interior e Investigador-Sênior do Centro em Rede de Învestigação em Antropologia (CRIA-Universidade Nova de Lisboa). Email: donizetti.rodrigues@gmail.com.

b Graduada em Ciências Sociais-Antropologia (UFPA) e Mestra em Ciências da Religião (Universidade do Estado do Pará). Email: ingrid_heinen@hotmail.com. 
Antes de apresentar a nossa etnografia, e para contextualizar o trabalho, é pertinente destacar o estudo da mais importante festa religiosa realizada no Pará, O Carnaval Devoto: um estudo sobre a festa de Nazaré, em Belém (1980), de Isidoro Alves. Nesta obra, o autor esclarece que os festejos de Nossa Senhora de Nazaré, de grande significado simbólico, estão fortemente marcados por expressões simbólicas-religiosas de origem portuguesas e amazônicas.

Segundo Alves (1980), existe na Amazônia um sistema de festas de Santos/Santas, intrinsecamente ligado à cultura regional, expresso na vivência social dos indivíduos que, em um período determinado, se afastam das suas experiências diárias e passam a viver, de maneira excepcional, as suas festas religiosas - manifestações simbólicas, eventos ritualizados em homenagem a um(a) Santo(a) padroeiro(a).

Neste contexto das fortes ritualidades religiosas, os Círios ocupam um lugar de relevo. De acordo com Alves (2005), os Círios são constituídos por festividades com procissões, romarias e arraiais. Durante o período da festa, há uma grande movimentação de fiéis, marcada pela confraternização, troca de experiências, auxílio mútuo e por uma forte reciprocidade e solidariedade social.

As festas de Santo apresentam, no catolicismo popular, arranjos culturais e conjuntos de significados e significações que lhes são próprios, tais como: a patronagem do(a) Santo(a), o mito de origem, a comensalidade, a estrutura particular de caráter popular dos festejos, entre outros. Este autor afirma ainda que esses eventos estão ligados a duas vertentes:

"Uma tratando-a como uma festa religiosa no sentido estrito e, portanto, sob o comando da autoridade religiosa ou a quem ela delegar poderes (a diretoria da Festa) e, outro, como uma festa popular, proporcionadora de manifestações mais livres e espontâneas, não submetidas aos rigores litúrgicos ou às regras impostas pela autoridade sacral. Trata-se de uma festa devocional, mas feita com um sentido mais abrangente, mais informal" (Alves 1980:15).

Desse modo, para entender os aspectos devocionais do Círio, é preciso compreender o efetivo sentido da festa de Nossa senhora de 
Nazaré, tendo em vista que, ao acompanhar a Santa, os fiéis estabelecem laços íntimos e diretos com ela e não apenas permeados pela hierarquia religiosa do catolicismo oficial.

Alves (1980) esclarece que a tríade, muito comum nas festas de devoção, relacionada às atividades de rezar, comer e dançar, pode ser observada no festejo em honra à Nossa Senhora de Nazaré e, em suas variações, nas diversas festas religiosas existentes no contexto paraense. De acordo com este autor, os acontecimentos de maior destaque do Círio de Nazaré, podem ser classificados em três categorias:

"A primeira seriam as procissões com o Círio servindo de paradigma; a segunda seria o arraial ou a festa propriamente dita com as relações entre o sagrado (os atos litúrgicos diários como missas, novenas e romarias) e o profano (o arraial, no Largo de Nazaré, um parque de diversões e entretenimento); a terceira ordem de eventos seria o almoço do Círio" (Alves 1980:30).

Nesse sentido, no Círio há um entrelaçamento no contexto do ritual marcado por momentos de celebração e respeito ao sagrado, bem como, por ocasiões de grande felicidade e descontração caracterizadas pelo encontro e reencontro entre as pessoas, pelas brincadeiras e por uma certa informalidade, típica, das manifestações populares (Alves 2005). Este importante evento religioso de Belém demarca o ponto de partida para uma série de outras ocorrências, da mesma natureza que acontecem em grande parte das cidades e vilas interioranas do Estado do Pará, "as quais realizam os seus Círios e homenageiam seus padroeiros. Todos subordinados à hierarquia do Santo Padroeiro maior, Nossa Senhora de Nazaré" (Alves 2005:322). Em cada ano, "o cumprimento ritual atualiza a passagem de um ciclo a outro, revela os desejos comunitários e o sentimento de pertencimento e a renovação de relações socialmente estabelecidas" (Alves 2005:317). Assim, todo o processo dos festejos revela as aspirações coletivas socialmente estabelecidas e o sentimento de pertencimento a um grupo social que partilha as mesmas crenças religiosas. 


\section{A comunidade quilombola, identidade religiosa e} relações de sociabilidade

A comunidade Vila do Cravo encontra-se situada em Concórdia do Pará, mais precisamente na divisa entre os municípios de Bujaru e Concórdia (mesorregião nordeste paraense ${ }^{1}$ ), distante 142 quilômetros da capital Belém. Um pequeno ramal de terra, com início no Km 35 da PA-140, viabiliza o acesso à localidade (figura 1). Segundo os dados de 2010, do Instituto Brasileiro de Geografia Estatística (IBGE), a comunidade tem cerca de 900 pessoas.
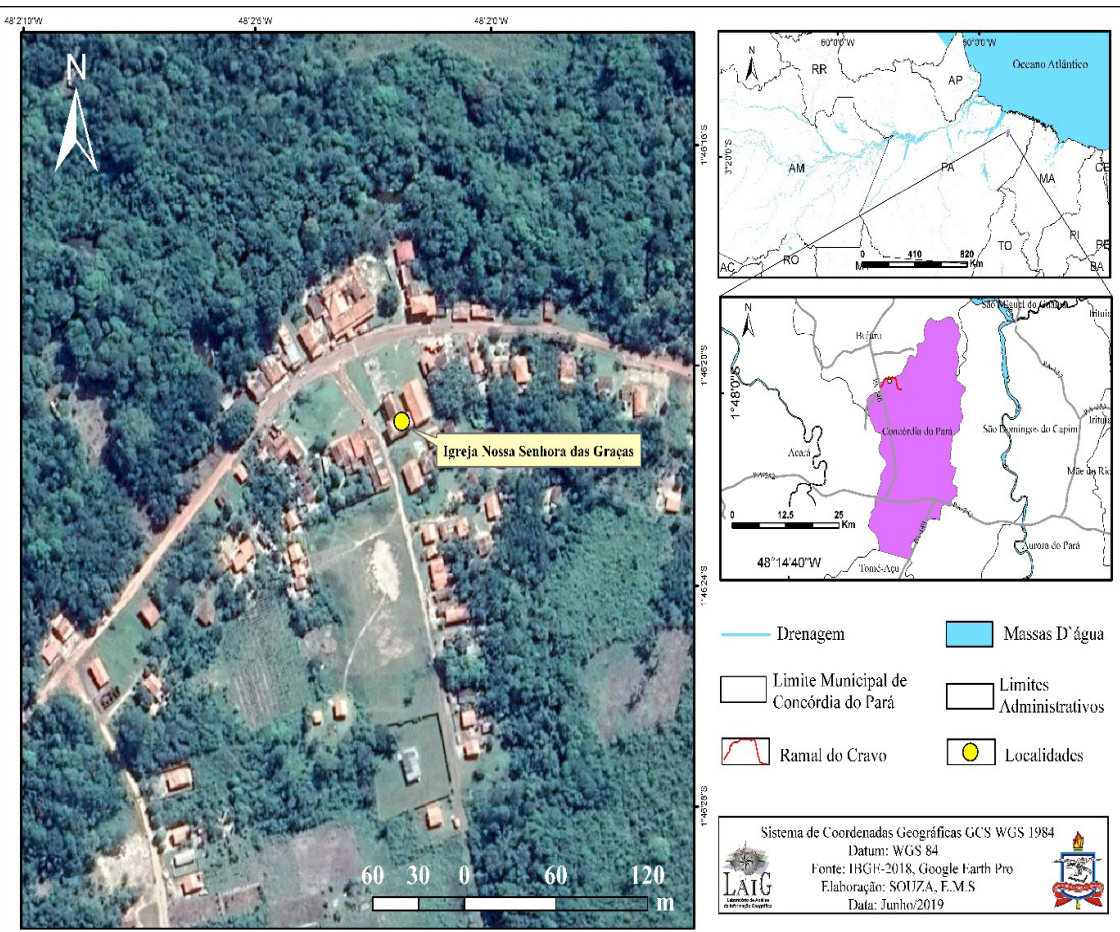

Figura 1 - Mapa da localização da Vila do Cravo.

Segundo Malcher (2011), os debates acerca da territorialidade quilombola na Vila do Cravo passaram a ocorrer na década de 1970, 
por meio dos grupos de evangelização que atuavam nas comunidades ligadas à paróquia de São Joaquim, no município de Bujaru. A autora esclarece que esses grupos de evangelização colaboraram para a formação de lideranças comunitárias locais e para a consolidação de outros movimentos, tais como: Comunidades Eclesiais de Base $(\mathrm{CEBs})^{2}$, Sindicato de Trabalhadores Rurais, Comissão Pastoral da Terra da Região Guajarina e os Círculos de Cultura ${ }^{3}$.

As discussões promovidas por essas organizações, sobre os direitos das comunidades remanescentes de quilombos, também foram fundamentais para a formação das associações quilombolas de Bujarú (Associação das Comunidades Remanescente de Quilombos Oxalá de Bujaru - ARQUIOB) e de Concórdia do Pará (Associação das Comunidades Remanescente de Quilombos Nova Esperança de Concórdia do Pará-ARQUINEC), fundadas em 2001.

A vila do Cravo se afiliou a ARQUINEC e, a partir de 2001, alguns moradores se engajaram mais fortemente nas discussões sobre a territorialidade quilombola e passaram a reivindicar, de forma legal, o reconhecimento do direito a terra. A Vila foi reconhecida como remanescente de quilombo no ano de $2006^{4}$. No entanto, em 2011, com a intenção de fortalecer ainda mais a luta pela titulação definitiva do território quilombola, lideranças locais criaram a Associação de Remanescentes de Quilombo do Cravo (ARQUIC) que, ainda hoje, reivindica, sem sucesso, a aquisição do título de terra reconhecido pelo Instituto Nacional de Colonização e Reforma Agrária (INCRA).

Edna Castro, na obra Quilombolas de Bujaru: memória da escravidão, territorialidade e titulação da terra (2003), faz alusão ao processo de ocupação das comunidades que hoje são reconhecidas como remanescentes de quilombos, no município de Bujaru (localidade próxima a Vila do Cravo) e em suas proximidades. A autora salienta que:

"A vila de Santana juntamente com o Arraial do Cravo, a primeira na margem esquerda do rio Bujaru e, o segundo, nas margens do igarapé Cravo, foram povoamentos importantes nos séculos 
XVIII e XIX. Dali irradiaram-se e teceram as relações de sociabilidade com outras localidades dando origem a novos povoados" (Castro 2003:156).

Ainda sobre a questão das comunidades que tiveram suas origens diretamente ligadas ao rio Bujaru, Castro enfatiza que:

"A população camponesa no círculo das comunidades que se localizam no entorno do rio Bujaru e dos igarapés Cravo, Curuperé, Guajará-Açu, entre outros, é predominantemente de origem negra. Um território étnico marcado por relações de sociabilidade, que no passado teria sido ocupado, por escravos ou homens livres de origem escrava" (Castro 2003:193).

Portanto, a construção do território de Bujaru teve como base uma pertença étnico-racial (negra) e identitária (quilombola). Os quilombolas conservaram, ao longo do tempo, seus vínculos e relações familiares e de vizinhança, trocas econômicas, festividades e manifestações religiosas, que lhes garantiram, até os dias atuais, a manutenção de um sistema coletivo de solidariedade social.

No que se refere à identidade religiosa predominante, Macedo $\&$ Sousa sinalizam que "o conceito de comunidade para os moradores [...] do Cravo está diretamente relacionado à presença da igreja católica na localidade" (2011:121). A edificação da primeira capela, em 1970, a realização de missas mensais e outras atividades religiosas e festivas contribuíram para uma concepção de comunidade ${ }^{5}$ assente na crença religiosa de base católica.

\section{A etnografia: o círio de Nossa Senhora das Graças ${ }^{6}$}

Dentro do ciclo de festividades da Vila ${ }^{7}$, o Círio é a festa religiosa de maior importância, pois reúne, no intervalo temporal que compreende o festejo, o maior número de devotos católicos da região. No dia 25 de novembro de 2018 ocorreu o terceiro Círio em homenagem à padroeira da comunidade, tema central do nosso trabalho.

Do ponto de vista metodológico, e seguindo a orientação de Geertz (1989), a etnografia intensiva foi realizada entre os dias 21 e 25 
de novembro de 2018, utilizando a observação-participante, com 'descrição densa', envolvendo símbolos, rituais e experiências do sagrado vividas no contexto da comunidade, a fim de compreender as estruturas significantes implicadas na ação religiosa observada. No trabalho de campo, foram realizadas entrevistas semiestruturadas com alguns participantes da festa religiosa, constituindo os key-informants ${ }^{8}$ deste estudo ${ }^{9}$, bem como acompanhou-se a organização do festejo e todo o percurso da romaria, conversando informalmente com os devotos e fazendo registros fotográficos. Vale frisar que na etnografia deu-se especial atenção à memória social do grupo, pois esse aspecto é crucial na reconstrução histórica da religiosidade local ${ }^{10}$.

O Círio foi instituído pelo representante oficial da igreja católica na comunidade, o padre Gregório Amorim. Segundo ele, em 2016, seu primeiro ano como pároco da região, surgiu a intenção de propagar em maior escala esta devoção que já existia na região desde a década de $1970^{11}$. Sobre a história deste evento religioso, ele profere o seguinte testemunho:

Eu lembro que no primeiro ano que a gente realizou os preparativos para o primeiro Círio, eu encomendei seis imagens pequenas, para que fizesse as novenas, peregrinações nas famílias e preparasse o povo para este momento do Círio. Confesso que não esperava que no primeiro ano o Círio tivesse dado tanta gente e depois a gente adquiriu uma imagem maior. A intenção mesmo foi de propagar a devoção ${ }^{12}$.

O período de festejos que abrange o Círio, no mês de novembro, é formado por uma série de eventos, tais como: peregrinação da imagem nas casas de algumas famílias da comunidade, romaria, arraial e uma missa solene. No ano de 2018, o tema oficial foi 'Com Nossa Senhora das Graças, celebramos 260 anos de caminhada paroquial' e o lema 'Eis aqui a serva do Senhor (Lucas 38)' 13 .

Do ponto de vista antropológico, as relações de reciprocidade, vizinhança e parentesco ainda são aspectos predominantes na comunidade da Vila do Cravo. Segundo Castro (2006), a luta pelo reconhe- 
cimento dos territórios quilombolas aproxima as comunidades dos municípios de Bujaru e Concórdia do Pará, como um seguimento constituído pela história comum de ocupação dessas regiões, formado por sólidos vínculos de solidariedade, trabalho com a terra, religiosidade e tradições culturais. Nesse sentido, toda a sequência de acontecimentos desta festividade religiosa é marcada por fortes relações de solidariedade ${ }^{14}$ : na organização e preparação da festa, na romaria, na peregrinação da imagem, nas famílias e vizinhanças, nas missas, no arraial ou no preparo e consumo de comidas típicas (figura 2).

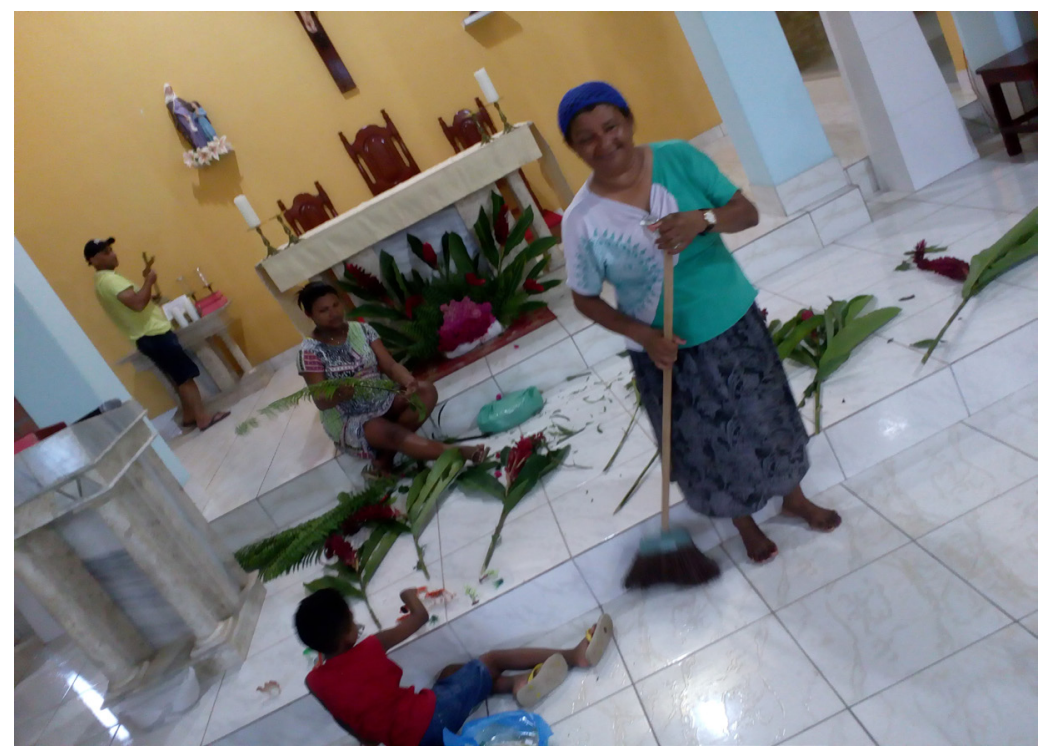

Figura 2 - Preparação da igreja.

Conforme ressalta o coordenador do festejo, André Barreto:

Graças a Deus nós temos muita ajuda [...] As pessoas ajudam arrumando, fazendo comida. Por exemplo, as pessoas que trabalham na cozinha amanheceram. Depois que terminou a festividade à noite, elas ficaram lá, uma equipe de oito mulheres, trabalhando 
até de manhã, isso é muito gratificante. E, também, têm as pessoas que menos participam da igreja, não vem no domingo, não vem na missa, mas quando chega um trabalho desse se doam muito, muito mesmo. Essas pessoas vieram ajudar a arrumar, em todos os trabalhos, na pintura da igreja. Olha como a igreja está bonita. A maioria dessas pessoas não têm aquela participação muito ativa na igreja. Aqui nós somos umas 25 pessoas que trabalham na coordenação da comunidade, só que vêm muito mais gente pra ajudar das pessoas que não são muito de estar na igreja. Essas pessoas quando têm trabalho perguntam o que tem pra fazer e dizem que estão aqui pra ajudar. Ontem, por exemplo, chegaram muitas pessoas se oferecendo pra ajudar no trabalho ${ }^{15}$.

Assim, é possível perceber que os moradores da comunidade, especialmente no período que compreende a festa, se unem para ajudar em diversas atividades que são necessárias para a efetiva consecução do evento. Desse modo, ainda comentando sobre a solidariedade social reproduzida e compartilhada pelo grupo quilombola no período do festejo, André salienta:

Nós convidamos algumas pessoas pra ajudar, mas muitas pessoas se oferecem. Desde a semana que vai se aproximando a festa do Círio, chega gente perguntando se tem alguma coisa pra fazer. Perguntam onde eles se encaixam nas atividades, se é na limpeza, na parte elétrica, na pintura. Muitas vezes um erro muito grande que a gente tem aqui, é porque vamos na casa daquelas pessoas mais próximas da igreja. Pensamos que a pessoa participa bem da igreja e queremos convidar pra ajudar e esquecemos das outras pessoas. Mas esse ano eu pensei em convidar muitas pessoas que nem sempre estão na igreja. As pessoas que gostam de ir pra festa, até pessoas que usam drogas e eles vieram ajudar. Isso é gratificante. Ontem as pessoas que estavam ajudando, falaram que valia a pena o esforço, disseram que estava muito bonito. As pessoas que estavam pintando, roçando e limpando arraial falaram que é muito gratificante. A comunidade é muito fiel com a igreja. Colaboramos bastante. Antes a arrecadação do dízimo era bem baixa, agora já passa dos dois mil reais por mês. E com o trabalho, sempre tem gente pra fazer mutirões, pintar e limpar a igreja"16.

$\mathrm{Na}$ Vila do Cravo há um forte sentimento de pertença à coletividade. A cooperação e comunhão, experienciadas durante a festivi- 
dade, contribuem para o fortalecimento das crenças e valores devocionais do grupo. Nesse sentido, uma das ajudantes que auxiliam na preparação da festa, Mirna Dantas, relata que a sua motivação para o trabalho voluntário é:

Primeiramente agradecer a Deus, por tudo o que Ele faz por nós. Eu acho que ainda é pouco o que a gente faz pra Ele. Então, eu acredito que vale a pena a gente fazer o sacrifício de largar a família, o trabalho e se colocar um pouco a serviço da comunidade para ajudar a todos. Pra mim é muito gratificante poder trabalhar e me doar para os outros, pra comunidade. Estou trabalhando na organização desde duas semanas atrás. Estamos empenhados em pintar, lavar e fazer a decoração. $\mathrm{Na}$ cozinha estou trabalhando a dois dias, ajudando a preparar as comidas pro arraial ${ }^{17}$.

Lauro Albuquerque é o coordenador da igreja local e responsável por conduzir as celebrações quando o padre não está presente. Por conhecer profundamente o circuito das arrecadações financeiras na instituição, evidencia a importância da colaboração e participação ativa dos moradores para a manutenção do templo religioso:

Sem o povão, sem a comunidade a igreja não seria possível. $O$ Cravo está assim hoje, graças a Deus primeiramente e depois graças ao povão pelas suas colaborações, sejam financeiras, sejam no trabalho, sejam na participação. Quanto maior a comunidade, maior a despesa, financeiramente falando. Nós temos como arrecadação o dízimo, as ofertas e as festas. São as entradas que nós temos e graças a Deus são entradas grandiosas. E com essas entradas nós mantemos a igreja. O povo do Cravo é que conduz essa igreja. Depois de Cristo é o povo do Cravo, seja com dinheiro, seja com a participação, seja com a oferta. É o povo do Cravo que conduz essa igreja. Sem o povo não tem igreja ${ }^{18}$.

Desse modo, é possível constatar que a religiosidade na Vila do Cravo é caracterizada por uma experiência comunitária ativa. A Santa padroeira da localidade representa o símbolo da união de grande parte dos moradores. Assim sendo, a devoção à Nossa Senhora das Graças simboliza a unidade do grupo, tendo em vista que os habitantes da Vila cooperam unidos, com ações práticas para a melhoria da 
vida coletiva. Sobre a vivência comunitária e a ajuda mútua, articulada pelos moradores, Lauro dá o seguinte testemunho:

Eu penso que é fundamental. Sem essa vivência comunitária não tem como ser feliz. Por exemplo, eu dizia na igreja que nós juntamos essa semana, os talentos do Cravo. Uma festa desse tamanho não é fácil de fazer se não fossem os talentos e essa vivência em comunidade. Aqui passaram durante essa semana mais de cem pessoas e é contagiante. A pessoa vai passando na rua e vê os outros empolgados trabalhando, logo vem e se junta. Essa vivência comunitária que nós temos aqui, eu acredito que sem ela não há vida no Cravo ${ }^{19}$.

$\mathrm{Na}$ noite que antecedeu a romaria, houve um ato litúrgico na igreja, realizado pelo próprio Lauro, constituído pela reza do terço, leitura do Evangelho e realização de preces. Praticamente, apenas as pessoas adultas e idosas participaram nesta celebração. As crianças e os jovens estavam concentrados ao lado de fora da igreja, mais interessados no arraial. Após pregar sobre alguns ensinamentos bíblicos, Lauro destacou que, em primeiro lugar, Deus foi o grande responsável pela realização deste festejo religioso e, em segundo lugar, ressaltou a importância da participação dos fiéis, que se uniram para organizar e concretizar a festa. Pontuou ainda que os moradores da comunidade precisam se ajudar mutuamente, pois prestar auxílio a todos é fundamental para realizar a vontade de Deus. As rezas, as preces, foram feitas principalmente visando a cura de doenças. Mas, também, se rezou pelas pessoas que trabalharam, incansavelmente, na preparação da festa, agradecendo a dedicação, o empenho e pedindo para que possam continuar ajudando nos próximos anos.

Após a celebração, os fiéis se encaminharam para a parte externa da igreja, formada por uma ampla área, que contém um cruzeiro e um salão comunitário, local destinado para as atividades do arraial: espaços determinados para exibições culturais de canto e dança, para a realização de um jogo com cartões numerados (bingo) e barracas para venda de comidas e bebidas não alcoólicas (figura 3). Há, também, um parque de diversões para as crianças, com balanços em for- 
mato de barcas, pula-pula inflável em forma de castelo, cama elástica e jogos de argola.

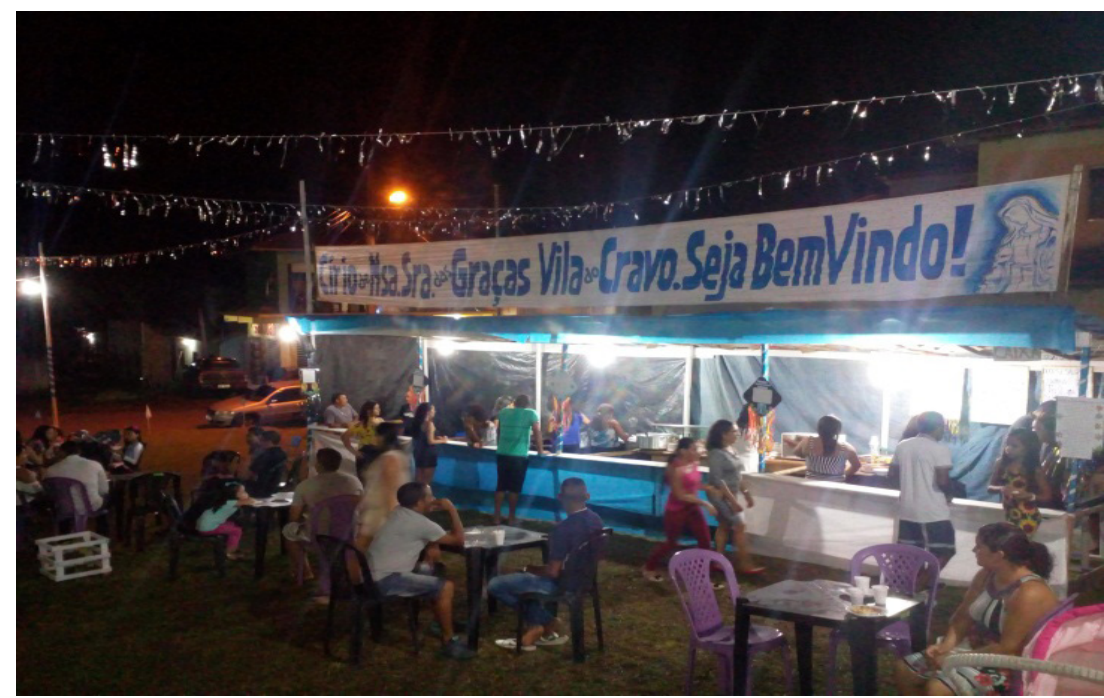

Figura 3 - Consumo de comida e bebidas não alcoólicas no arraial.

A festa dura dois dias: na noite que antecede e no dia que ocorre a romaria. Na noite anterior, um músico local cantou alegres melodias e um grupo, composto por mulheres, todas moradoras da comunidade, apresentou uma dança típica paraense: o carimbó. As apresentações foram muito aplaudidas e animaram a noite dos presentes, que prestigiavam o arraial: as crianças, que apreciavam tudo com grande animação, e os adultos, que sorriam entusiasmados e conversavam sem cessar com parentes e vizinhos.

No domingo, dia em que ocorreu a romaria, houve uma missa na igreja de Nossa Senhora do Perpétuo Socorro. A igreja se encontra no Km 35 da PA-140, exatamente no local onde se inicia o ramal de terra que dá acesso à Vila do Cravo. A missa, celebrada pelo padre Gregório, começou às oito horas da manhã e teve a duração de uma hora. Logo a seguir, deu-se início a tão esperada romaria. 
A imagem da padroeira é posta numa berlinda, ornamentada com flores amarelas e brancas. É carregada por homens, denominados 'guardas da santa', que a acompanham em todo o trajeto da romaria, desde o início do ramal do Cravo até a igreja local, contabilizando, aproximadamente, $3 \mathrm{~km}$ de percurso (figura 4).

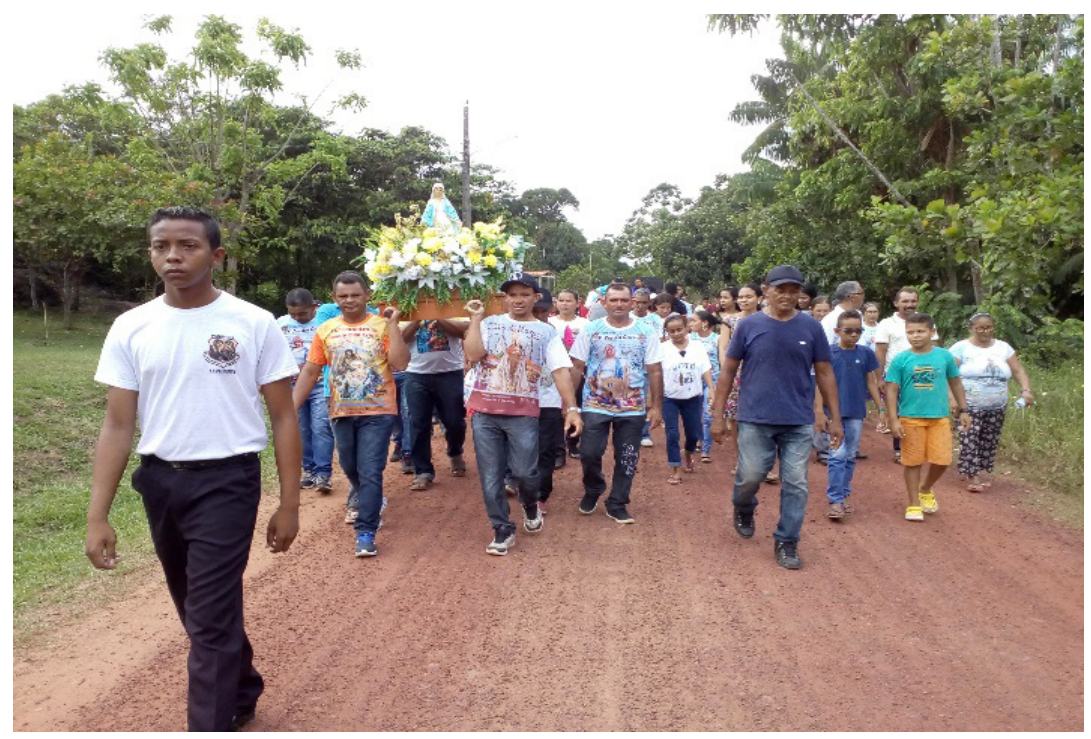

Figura 4 - A romaria pelo ramal do Cravo.

A grande maioria dos fiéis segue a imagem, sempre louvando e dando graças. Um grupo de canto, constituído por jovens moradores da região, acompanha a romaria em um automóvel, entoando canções religiosas que emocionam os devotos. Os fiéis mais idosos, impossibilitados fisicamente, fazem o trajeto em automóveis, que se deslocam lentamente, para seguir de perto a berlinda. Algumas pessoas participam em motos, principalmente, os jovens. Há, também, um carro repleto de crianças, algumas vestidas de anjos.

O celebrante Lauro passou todo o percurso da romaria lendo determinadas passagens do Evangelho, fazendo orações para agradecer 
as bênçãos recebidas e pedindo auxílio para solucionar problemas, de natureza material e espiritual, dos moradores locais. Havia devotos distribuindo garrafas de água como forma de agradecimento pelas graças alcançadas, nomeadamente a cura de doenças. Alguns fiéis relataram que prometeram a Santa "oferecer água aos participantes da romaria todos os anos, pois, é uma maneira de se demonstrar gratidão pelos benefícios alcançados" (notas do diário de campo).

Em alguns pontos do ramal do Cravo, quando a imagem passa em frente à residência de determinadas famílias, há um grande foguetório, seguido de aplausos para exaltar a Santa (figura 5). Muitas casas são enfeitadas com balões e exibem faixas com solicitações, intercessões e reverencias à Nossa Senhora das Graças (figura 6).

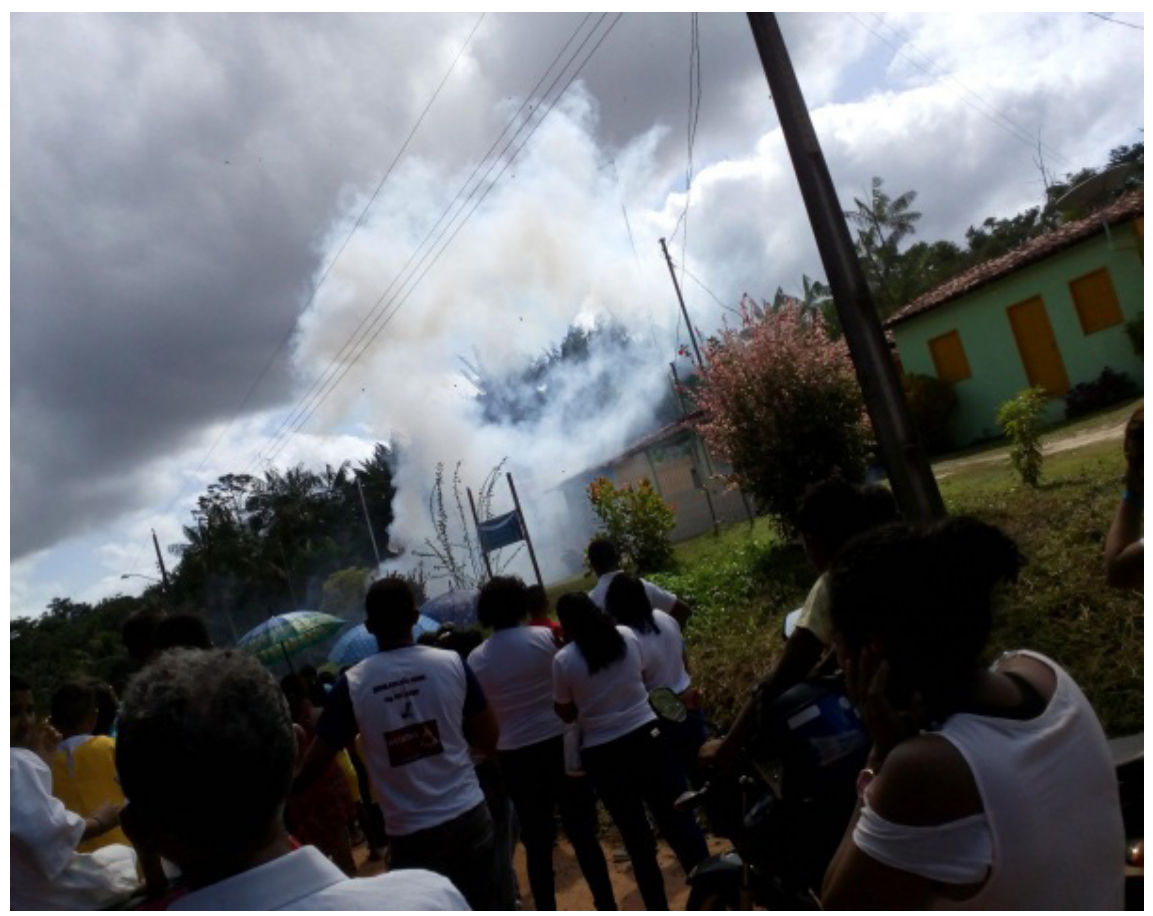

Figura 5 - Foguetório na residência da família Sales da Conceição. 


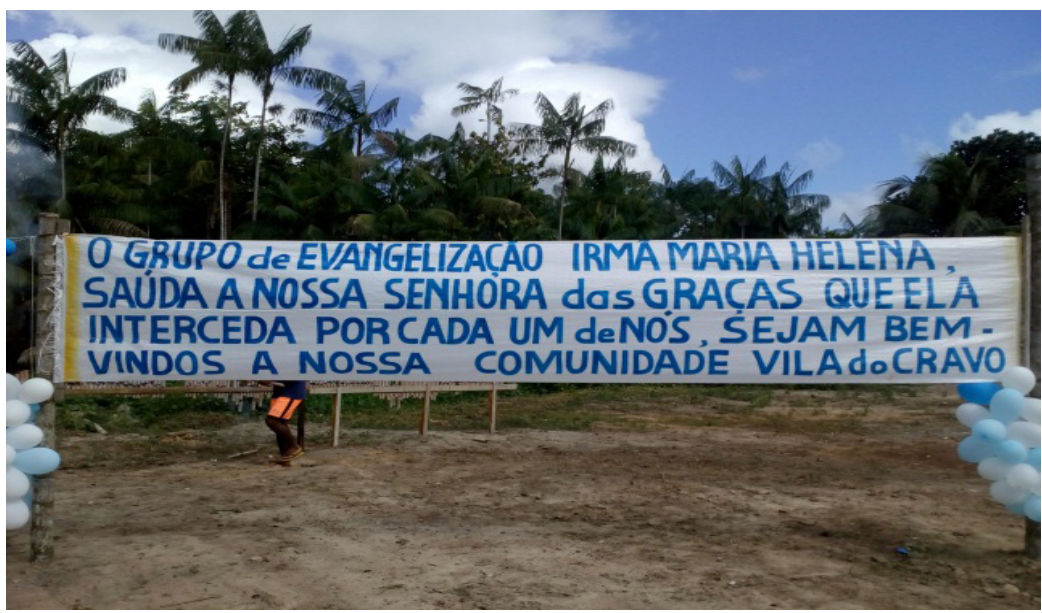

Figura 6 - Faixa do grupo Irmã Maria Helena para homenagear a padroeira.

Como vimos, há muitas homenagens, agradecimentos e pedidos durante todo o percurso da romaria. Quando a imagem da padroeira chega de volta à igreja, muitos devotos já a esperam, com ansiedade, para reverenciá-la, tocá-la e fazer-lhe súplicas. O templo fica lotado, pois, além dos fiéis que aguardam a chegada da imagem, grande parte das pessoas que acompanham todo o trajeto também participa da missa de encerramento (figura 7).

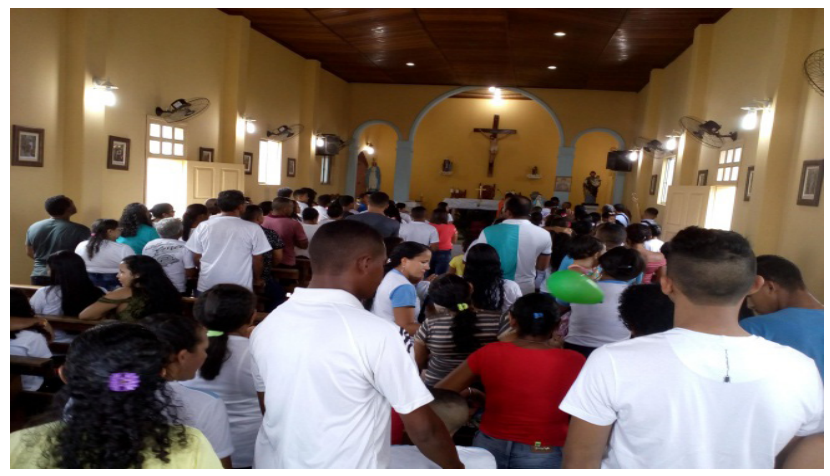

Figura 7- Missa de encerramento da romaria na igreja da comunidade. 
Durante o ato litúrgico, os devotos aclamam fervorosamente a Santa, com cânticos e orações. Durante o sermão, o padre Gregório agradece a participação, em massa, dos devotos e a cooperação dos moradores para organizar e colocar em prática o festejo. Ao final da celebração, os fiéis se aproximam da imagem padroeira, a fim de agradecer e fazer novos pedidos (figura 8).

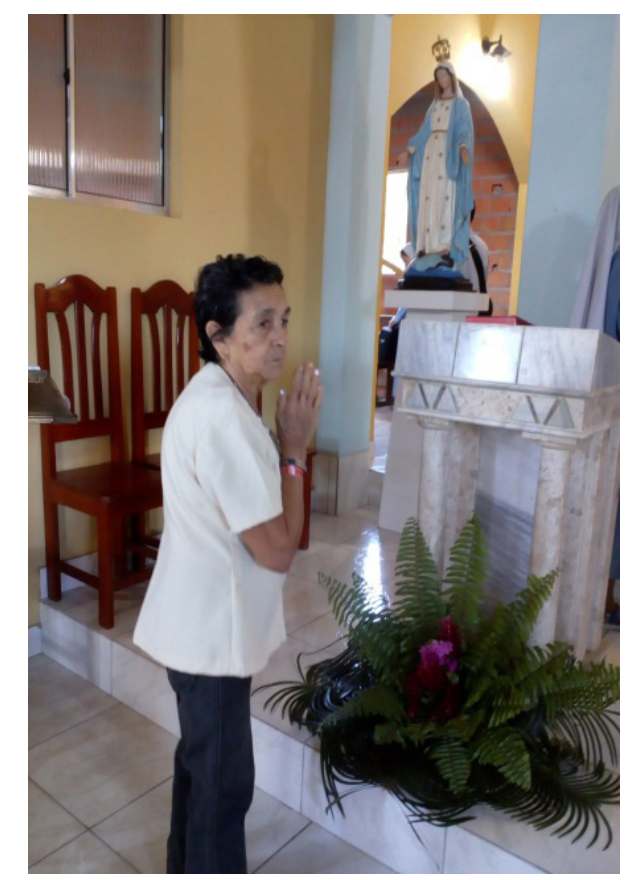

Figura 8 - Agradecimentos e pedidos a Santa.

Após o encerramento da missa, por volta do meio-dia, as pessoas se reúnem para prestigiar o arraial que já decorria nos arredores da igreja. Os vizinhos e familiares almoçam juntos, no salão comunitário, onde podem comprar cartelas para concorrerem aos prémios do jogo do bingo. Conforme pontuou o coordenador da instituição religiosa, o dinheiro arrecadado com as vendas de almoços e do bingo é doado 
para a igreja local, a fim de ser utilizado na manutenção da sua estrutura física e nos projetos assistenciais.

Feita a 'descrição etnográfica densa', envolvendo símbolos, rituais e experiências do sagrado vividas no contexto da romaria, é altura da construção da narrativa antropológica, a fim de compreender as estruturas significantes implicadas nesta ação religiosa observada (Geertz 1988).

\section{Análise sócio-antropológica da romaria}

Uma primeira questão que é pertinente discutir nesta análise refere-se às funções sociais da religião. Em segundo, a romaria como expressão da solidariedade social.

Para Émile Durkheim, a religião "um sistema solidário de crenças e de práticas relativas a coisas sagradas" (1996:32), como representação coletiva compartilhada, possui uma função integradora capaz de manter a solidariedade social. $\mathrm{O}$ autor realça que "as crenças propriamente religiosas são sempre comuns a uma coletividade determinada [...]. Tais crenças não são apenas admitidas, a título individual, por todos os membros dessa coletividade, mas são próprias do grupo e fazem sua unidade" (1996:28). Em virtude disso, os indivíduos que constituem essa coletividade acabam se sentindo unidos entre si. Ou seja, a religião se caracteriza pela unidade do grupo que compartilha as mesmas crenças. Consequentemente, a religião é, na sua essência, produto da ação de indivíduos reunidos em grupos sociais. Segundo ainda Durkheim,

"Para explicar a religião, para a tornar racionalmente inteligível [...] é necessário encontrar no mundo [...] uma fonte de energias superiores àquelas de que o indivíduo dispõe e que, no entanto, possam comunicar com ele. Ora, pergunto se esta fonte pode ser encontrada nalgum outro sítio a não ser nessa vida tão particular que resulta dos homens associados. Efetivamente, sabemos por experiência que, quando os homens estão reunidos, quando vivem uma vida comum, da sua reunião surgem forças excepcionalmente integrais que eles não conhecem na vida privada" (Durkheim 1996:283). 
Seguindo as ideias de Durkheim (1996), sobre as funções sociais da religião, Donizete Rodrigues afirma que:

"Por detrás de toda manifestação religiosa (rito, culto, credo, adoração, etc.) está a sociedade, pois foi ela que criou a (sua) concepção de religioso. Deus, por exemplo, que é talvez a concepção humana mais forte dentro do contexto do sagrado, era uma forma de sacralização ou mitificação (no plano transcendental) de meras leis, usos, costumes, valores e tradições do grupo social. Portanto, o culto a Deus era no fundo um culto a própria sociedade e a religião era apenas uma forma suprema de consolidar o social, de perpetuar a cultura; toda manifestação religiosa permite, no fundo, aos membros da sociedade reafirmar-se simbolicamente como grupo e actualizar e reforçar os valores colectivos" (Rodrigues 2007:88).

Nessa acepção, a religião pode ser compreendida como fenômeno social, em que diferentes escalas (individuais e coletivas) de experiências sociais são agregadas e direcionadas em torno de finalidades socialmente definidas. Dessa maneira, de acordo com esta perspectiva funcionalista, a religião é caracterizada como um conjunto de complexos sistemas de práticas rituais e representações simbólicas, fenômeno essencialmente humano que opera na constituição de categorias do pensamento que orientam a vida social. Sendo assim, a religião se expressa pela ação dos indivíduos reunidos em grupos sociais: "é uma coisa eminentemente social. As representações religiosas são representações coletivas que exprimem realidades coletivas" (Durkheim 1996:16). Nesse sentido, o autor reitera que:

"É pela ação comum que ela (a religião) toma consciência de si e se afirma; ela é, acima de tudo, uma cooperação ativa. Mesmo as ideias e os pensamentos coletivos só são possíveis graças a movimentos exteriores que os simbolizam. [...]. Portanto é a ação que domina a vida religiosa, pelo simples fato de a sociedade ser a sua fonte" (Durkheim 1996:461-462).

De acordo com Durkheim, as religiões são constituídas pela divisão da realidade social em dois gêneros opostos, o sagrado e o profano. A esfera sagrada é composta de um conjunto de crenças e de ritos, "[...] representações que exprimem a natureza das coisas sagradas e a 
relação que elas mantêm [...] com as coisas profanas. Enfim, os ritos, são regras de conduta que prescrevem como o homem deve comportar-se com as coisas sagradas" (1996:24).

As esferas religiosas e profanas não podem existir, simultaneamente, em um mesmo ambiente: "para a manifestação do sagrado, é preciso haver um local especial onde o profano esteja excluído. Daí a instituição de templos e santuários" (Durkheim 1996:326). Igualmente, "elas não podem coexistir no mesmo período de tempo. Daí a necessidade de reservar exclusivamente ao sagrado determinadas dias ou datas especiais. E assim surgiram as festas religiosas" (Durkheim 1996:327).

Tendo em conta a concepção durkheimiana sobre os campos sagrado e profano, é pertinente ressaltar que mesmo sendo executadas de acordo com determinados preceitos da instituição oficial, que enaltecem a esfera sagrada, as festas de devoção escapam ao seu domínio estrito, pois "atuam de um lado a ordem e o respeito e, de outro, a informalidade, a camaradagem, o gesto festivo, o encontro a não-obediência às regras formais, pode-se inferir que é pela neutralização entre essas partes que se caracteriza a Festa" (Alves 1980:28). O fiel respeita a autoridade sacerdotal, todavia conduz a festividade como um evento repleto de características profanas, mesmo que inconscientemente.

Em sintonia com o pensamento de Alves (1980), António Costa assinala que, nas festividades religiosas populares, "a efervescência festiva emula o paroxismo dos eventos rituais. A festa popular com tônica religiosa alia o sentido solene ao divertimento público, despido da seriedade ritualística" (Costa 2011:198).

Nesse entendimento, os adeptos do catolicismo popular procuram ultrapassar as diferenças que se entrepõem entre a esfera humana e a sagrada, criando uma conexão direta com o(a) Santo(a) padroeiro(a) de sua devoção para estabelecer os seus próprios elementos de conciliação entre ambos os domínios.

Neste sentido, o Círio pode ser definido como um ambiente no qual ocorre a confluência entre o sagrado e o profano. No entanto, 
mesmo havendo tal confluência, os dados etnográficos revelam a inexistência de uma clara distinção dessas duas categorias pelos fiéis que participam da festividade. A realização de atividades profanas, como o arraial, se não ultrapassam os limites definidos pela instituição oficial, são entendidas como um complemento, não sendo, portanto, antagônicas aos elementos sagrados que envolvem o circuito do festejo.

Nas comunidades rurais, campesinas, onde o catolicismo oficial não apresenta força institucional, os romeiros exteriorizam uma adoração a uma entidade religiosa repleta de fatores ligados a tradições e crenças da cultura local. Os devotos, nessa perspectiva, vivenciam cotidianamente um catolicismo popular com características particulares, onde a ritualidade é construída sincreticamente, associando os costumes locais com os preceitos do clero. Em conformidade com tal assertiva, Donizete Rodrigues explica que:

"Em muitos contextos sociais, as práticas e as superstições populares estão misturadas com os dogmas oficiais das Igrejas/religiões instituídas. De acordo com os meios e as circunstâncias, tanto as crenças como os ritos, preconizados pelas instituições religiosas oficiais, são praticados e sentidos de maneiras diferentes" (Rodrigues 2007:93).

Conforme realçou este autor, nas festas religiosas populares é (quase) impossível separar as dimensões do sagrado e as ações profanas. Ou seja, "é extremamente difícil fazer uma distinção entre o que é sagrado e o que é profano, pois há uma (quase) total sacralização das práticas profanas" (Rodrigues 2007:72). Sendo assim, a ligação desses diferentes aspectos é que propicia uma dimensão peculiar ao festejo de Nossa Senhora das Graças, pois possibilita uma associação entre o eixo sagrado e o eixo profano, criando um ambiente de harmonia em que a Santa de devoção é, categoricamente, responsável pela união dessas duas categorias opostas.

$\mathrm{Na}$ nossa etnografia, constatamos que existem devotos que se ocupam, exclusivamente, de pagar promessas. No entanto, há romeiros que também participam intensamente de todos os eventos da festividade, especialmente do arraial. $\mathrm{O}$ devoto, nesse contexto, paga sua 
promessa, renova seus votos com a Santa, acende velas aos pés da imagem, assiste missas, acompanha a procissão, compra alimentos, direciona as crianças para o parque de diversões, participa de jogos de argolas e do bingo, transitando, desta forma, entre todos os domínios da festividade sem grandes distinções. Conforme ressaltado anteriormente, o fiel, ao participar da festa da Santa, não dissocia de maneira efetiva as categorias sagrado e profano, pois o período do evento "são dias sim, de um intenso, por vezes dramático, encontro que envolve fé, alegria, festejos e sentimentos profundos" (Alves 2005:315).

Para se compreender o fenômeno das festas religiosas, no contexto amazônico, dois autores de leitura obrigatória são Eduardo Galvão e Heraldo Maués.

Heraldo Maués (1995) esclarece que, na região amazônica, a religiosidade católica não é marcada pela representação da orientação oficial da Igreja Católica, mas sim por uma forma específica de catolicismo popular.

"O catolicismo popular é aqui entendido em oposição ao catolicismo oficial, isto é, àquele que é professado pela igreja como instituição hierárquica estabelecida, que o procura incutir no conjunto da população [...]. Entendo, pois, por catolicismo popular aquele conjunto de crenças e práticas socialmente reconhecidas como católicas, de que partilham sobretudo os não especialistas do sagrado" (Maués 1995:17).

Para esses autores, a religiosidade popular se expressa, principalmente, no culto dos Santos, mais especificamente, na devoção de suas imagens. Os Santos e Santas locais, representados em imagens, apresentam características de divindade com poderes de atuação direta e não somente ações intercessoras. Dessa forma, o Santo é um dos elementos religiosos fundamentais do catolicismo popular na Amazônia, pois o fiel relaciona-se o tempo todo com o Santo de sua devoção, pedindo-lhe proteção, saúde e agradecendo pelas bem-aventuranças recebidas.

Os Santos podem ser considerados, segundo Galvão (1955), como divindades que defendem a comunidade contra males e todos os tipos 
de adversidades. Contudo, vale frisar que o relacionamento entre o indivíduo e o Santo é baseado em um contrato de reciprocidade, caracterizado pela promessa. No entanto, se o fiel não cumprir sua parte do pacto, o(a) Santo(a) não assegura a proteção e o auxílio almejados. Desse modo, as promessas são cumpridas antecipadamente, para não haver possibilidade de o Santo não retribuir o benefício solicitado.

Portanto, a relação entre fiéis e Santos de devoção baseia-se na dinâmica de trocas, reais e simbólicas, firmada pelo compromisso estabelecido entre ambos de pedir, ser atendido e agradecer pela benção recebida; o devoto faz um pedido, promete realizar algo para obter o que pediu, alcança a graça desejada e cumpre a promessa. Tal sistema de trocas, na lógica de Marcel Mauss (2003), é concretizado nas festas de Santo e o compromisso entre a entidade religiosa e o devoto é reafirmado. A promessa é cumprida como forma de agradecimento pela graça alcançada e para que o relacionamento entre os dois mantenhase inabalável.

Nessa perspectiva, a imagem de um Santo possui grande importância para uma comunidade, uma vez que "[...] acredita-se que determinadas imagens tenham poderes especiais, capacidades de milagres e de maravilhas que outras idênticas não possuem" (Galvão 1955:40). Dessa maneira, as representações dos Santos, as imagens, são protagonistas de uma determinada localidade e para elas são voltadas às crenças e as adorações da população.

A manifestação suprema do culto aos Santos é observada na festa com que se comemora o seu dia especial. Galvão (1953) esclarece que, na região amazônica, todo lugarejo ou comunidade possui seu Santo padroeiro de devoção e, anualmente, uma festividade é dedicada a ele. Neste contexto, as festas são comemorações coletivas de uma crença que congrega toda a comunidade.

Segundo Maués, as festas de Santo apresentam um elemento lúdico inerente a sua estruturação, conferindo aos festejos uma relevância singular. Um exemplo disso é que "um jogo de futebol como parte das comemorações da festa de Santo [...] não é, certamente, um jogo 
comum. E o mesmo se pode dizer das brincadeiras de arraial, das comidas, dos leilões, da bebida e da própria festa dançante" (2011:8). Assim, as categorias sagrado e profano não estão em contradição no decorrer das festas de Santo; são, na verdade, complementares, mesmo havendo uma hierarquia que, na maioria das vezes, enaltece a esfera sagrada.

Nas celebrações das festividades estão presentes elementos sagrados e profanos, entretanto, encontram-se distribuídos nas diversas etapas dos festejos. A maneira de organizar as festas e os seus diversos momentos constituintes é que distinguem estas duas categorias. Nesse contexto, Maués assinala que a diversão dos promesseiros (prática profana) não é de fato condenada, contanto que cumpram sua promessa de devoção (prática sagrada):

"Condenam-se, evidentemente, os excessos e a bebedeira durante a procissão e aprova-se a atitude do padre que 'debate' (combate) esses excessos; mas contanto que a obrigação (devoção) venha antes da diversão, o divertimento do devoto fica justificado [...] Assim [...] a devoção do santo, que se expressa de maneira mais enfática no momento da festa, não pode limitar se aos atos rituais 'sagrados': missas, novenas, orações contritas, sacramentos” (Maués 2011:7-8).

Nessa acepção, as esferas sagrada e profana, existentes nas festas religiosas populares, representam importantes momentos de confraternização coletiva entre diversas famílias de uma comunidade, possibilitando ao grupo o sentido de unidade e os reunindo em torno de uma devoção.

Tendo em conta a romaria que ocorre durante o Círio de Nossa Senhora das Graças, é importante destacar que durante o seu decorrer, os fiéis caminham, de maneira coletiva, fazendo preces para pedir auxílio e para glorificar a entidade milagrosa que concedeu os benefícios solicitados. Assim, a romaria é marcada pela dinâmica do ir e vir entre os devotos, cujas relações experienciadas no percurso estreitam os laços sociais. Todo o grupo de fiéis externaliza sua fé coletivamente, através das homenagens ao Santo ou à Santa de devoção e na visita ao santuário para rogar e agradecer pelas graças recebidas. 
Segundo Alves, nos festejos religiosos "se, ao mesmo tempo, há uma ordem estrutural manifesta, há também um espírito comunitário vivenciado pelos participantes dos diferentes eventos que compõem a festa" (1980:28). Assim, as romarias cumprem um papel primordial ao possibilitar o encontro entre uma pluralidade de indivíduos com experiências de vida distintas que estão unidos em torno de finalidades comuns, como cumprir uma promessa ou agradecer por um benefício obtido. A maneira como a fé é expressa nas romarias, mesmo havendo desejos particulares de cada devoto, acontece de forma coletiva e comunitária, de modo que a experiência religiosa partilhada pela coletividade contribui para a comunhão e manutenção das crenças e valores devocionais do grupo.

Seguindo essa linha de raciocínio, Costa (2011) pontua que os festejos religiosos populares, que agregam uma quantidade abundante de fiéis, assumem uma função de grande relevância no fortalecimento da solidariedade grupal e no reforço dos vínculos internos da congregação religiosa.

Nesse sentido, nas romarias, a vivência de caráter individual ligada a ambições pessoais é deixada em segundo plano. Os acontecimentos se desenvolvem de modo coletivo, prevalecendo os interesses do grupo que caminha junto às mesmas convicções. A experiência com o sagrado acontece comunitariamente, de modo que os fiéis se organizam para peregrinar em devoção a uma determinada entidade religiosa, considerada milagrosa e, assim, fazem pedidos e expressam gratidão, pagando promessas, pela cura de doenças, pela resolução de problemas financeiros e por todo tipo de graças alcançadas.

Para além da romaria, o processo de estruturação de um Círio, envolvendo o planejamento e a realização efetiva, proporciona aos devotos momentos de convivência que refletem relações de solidariedade social, capazes de levar o indivíduo a se dedicar ativamente a uma vivência em comunidade. Conforme as declarações proferidas pelos interlocutores, o sentimento de solidariedade e a ajuda mútua em prol da realização da festa da padroeira existem desde que se iniciam os primeiros preparativos para o festejo. 


\section{Considerações finais}

Em conformidade com a análise sócio-antropológica feita nesse trabalho, fortemente apoiada em Durkheim, Mauss, Geertz, Galvão e Maués, podemos afirmar que nos festejos de Nossa Senhora das Graças existe uma ordem de acontecimentos que são misturas de situações espirituais e materiais, exteriorizadas de diversas maneiras através dos inúmeros modos de rezar, falar, louvar, comer, brincar, etc. Dessa maneira, características tidas como profanas carregam, também, algum elemento sagrado na ocasião em que se integram no âmbito das festas da padroeira.

Neste contexto, como representações e práticas religiosas no âmbito do catolicismo popular, a comunhão das crenças e valores devocionais, dos que participam do Círio - e mais especificamente na romaria, evidencia a força do processo que envolve o devotamento, haja visto que, durante as festividades, os fiéis se unem em torno de uma finalidade comum. Nesse sentido, a exteriorização da religiosidade popular, por meio da festa, estabelece relações de solidariedade, uma temporalidade favorável à reciprocidade social entre os fiéis devotos, que partilham as mesmas convicções e graças alcançadas, devido a ação da Santa de devoção.

$\mathrm{Na}$ Vila do Cravo, as atividades que compõem esta festividade têm sua programação regulada de maneira oficial pela Igreja Católica, representada pelo pároco local. Entretanto, os devotos estabelecem uma dinâmica comemorativa própria, que pode ser definida em todo o seu processo por situações, como as missas e a romaria, que expressam um profundo respeito pelo sagrado e por uma euforia festiva profana, marcada pelo arraial, pelas músicas, pelas comidas típicas da região, pelas brincadeiras e pelas apresentações culturais.

Para finalizar, e seguindo a concepção durkheimiana, a religião se afirma no contexto social através das ações coletivas dos indivíduos, sendo desta forma a reverberação de uma cooperação ativa. Nessa perspectiva, a festa de Nossa Senhora das Graças possui uma função integradora capaz de manter a solidariedade social entre os participan- 
tes, visto que é uma representação coletiva (com)partilhada. Participar da festividade da Santa padroeira possibilita uma experiência com o sagrado e com a congregação de indivíduos que reza, canta, fala, agradece e cumpre promessas, mas propicia, também, o estreitamento dos vínculos coletivos. Conforme constatámos na nossa etnografia, há uma atitude cooperativa que acompanha toda a preparação do Círio, desde a fase inicial, com a mobilização das pessoas para organizar o festejo, até a etapa final com o encerramento da festa. No entanto, mal a festa acaba, começam os preparativos para a festa do próximo ano. A comunidade retorna a sua rotina quotidiana, marcada pelas práticas profanas, mas fortemente impregnadas de sacralidade.

\section{Notas:}

1 Esta região é composta por 20 municípios: Santa Luzia do Pará, São Miguel do Guamá, Tomé-Açu, Ulianópolis, Concórdia do Pará, Rondon do Pará, São Domingos do Capim, Ábel Figueiredo, Aurora do Pará, Bujaru, Cachoeira do Piriá, Capitão Poço, Dom Eliseu, Garrafão do Norte, Ipixuna do Pará, Irituia, Mãe do Rio, Nova Ésperança do Piriá, Ourém e Paragominas.

2 Macedo \& Sousa (2016) esclarecem que as CEBs fomentaram um estilo local de vida pautado na realização de práticas religiosas, bem como, na efetivação de ações políticas e sociais que foram fundamentais no processo de (re)conhecimento acerca das raízes históricas e étnico-identitárias de ocupação da região, contribuindo, desta forma, para a consolidação das comunidades remanescentes de quilombos dos municípios de Bujaru e Concórdia do Pará.

3 De acordo com Malcher (2011), os Círculos de Cultura, para além das ações sociais, incentivavam o resgate da memória ancestral. No caso específico da Vila do Cravo, as discussões foram lideradas pela Antonina Borges Santana, que reside na Vila há mais de 50 anos e já coordenou inúmeras ações para a melhoria social da sua comunidade. Ela iniciou também um movimento de reflexão com relação às origens e ancestralidade do povo do Cravo, intencionando fomentar o reconhecimento étnico e uma consciência de luta política entre os moradores.

4 Certidão de Reconhecimento: $n^{\circ}$ 01420.002940/2006-59. Livro de cadastro geral: No 008, Registro: № 883, Folha 45. Brasília, DF. 28 de setembro de 2006.

5 Charles Wagley, no livro Uma Comunidade Amazônica: estudo do homem nos trópicos (1957), expressa com muita clareza o sentido de comunidade utilizado no nosso estudo. Para o autor, "É nas suas comunidades que os habitantes de uma região ganham a vida, educam os filhos, levam uma vida familiar, agrupam-se em associações, 
adoram seus deuses, têm suas superstições e seus tabus e são movidos pelos valores e incentivos de suas determinadas culturas. Na comunidade a economia, a religião, a política e outros aspectos de uma cultura parecem interligados e formam parte um sistema geral de cultura [...] Todas as comunidades de uma área compartilham a herança cultural da região e cada uma delas é uma manifestação local das possíveis interpretações de padrões e instituições regionais" (Wagley 1957:43-44).

6 Este trabalho é parte da pesquisa da dissertação de mestrado, intitulada "Religiosidade na Amazônia Paraense: uma etnografia da comunidade quilombola Vila do Cravo, Concórdia - PA", realizada pela mestranda Ingrid Heinen e orientada pelo professor Donizete Rodrigues. A pesquisa está sendo desenvolvida no Programa de Pós-Graduação em Ciências da Religião da Universidade do Estado do Pará. Assim, a observação-participante, as entrevistas semiestruturadas e as fotografias foram executadas por Ingrid Heinen que é natural da região e realiza trabalho de campo na comunidade desde o início de 2018. Os dados coletados na etnografia foram analisados por ambos os autores para a elaboração deste artigo.

7 Há na comunidade duas festas em homenagem à Nossa Senhora das Graças: uma no mês de maio, caracterizada pela realização de novenas nas casas de alguns moradores e o Círio no mês de novembro. As novenas acontecem na Vila desde a década de 1970 e, antes do Círio ser instituído, os fiéis expressavam sua devoção através dos cânticos, leituras bíblicas e orações realizadas em tais eventos religiosos. Desde esta época, ao final de cada novena, há os tradicionais leilões e o jogo do bingo, que visam arrecadar fundos para igreja, bem como, a produção de comidas e bebidas não alcoólicas para serem degustadas, objetivando a confraternização dos devotos. Apesar das novenas reunirem uma grande quantidade de fieis católicos, o pároco local, em 2016, decidiu, em conjunto com a comunidade, instituir o Círio para propagar a devoção à Santa padroeira por todo o circuito da Vila, visto que a romaria do Círio começa na igreja localizada no início do ramal do Cravo e percorre, aproximadamente, $3 \mathrm{~km}$ até chegar a igreja da comunidade.

8 "Individuals with whom the researcher begins in data collection because they are well informed, accessible, and can provide leads about other information" (Creswell 1998:247).

9 Seguindo rigorosamente os princípios legais e éticos, obrigatórios neste tipo de estudo, foram previamente garantidas as autorizações para a realização da pesquisa e divulgação das imagens. Para garantir o anonimato dos principais interlocutores, os seus nomes foram alterados.

10 Conforme pontuado por Aldrin Figueiredo, em artigo intitulado "Um Natal de Negros: esboço etnográfico sobre um ritual religioso num quilombo amazônico", o sentido de memória social está relacionado a "um discurso construído pela comunidade para relatar a sua história, um discurso que pode ser apreendido desde as tradicionais entrevistas com os moradores, indagando os significados da festa, até a não menos tradicional observação atenta do ritual e sua apresentação" (Figueiredo 1995:225).

11 Como foi realçado, a devoção à Nossa Senhora das Graças já existia na Vila do Cravo desde os anos de 1970, época em que foi fundada a igreja. A edificação da igreja decorreu da união dos moradores do Cravo, que trabalharam de forma braçal, bem como, ofertando dinheiro, entre outros itens advindos do roçado, para arrecadar o montante necessário para a compra dos materiais de construção. 
12 Entrevista semiestruturada realizada com o padre Gregório Amorim, em 25 de novembro de 2018.

13 A Vila do Cravo está vinculada à paróquia São Joaquim e Sant'na (Bujaru-PA). Sendo assim, no ano de 2018, o tema do Círio homenageava os 260 anos de existência da supracitada paróquia.

14 De acordo com Castro (2006), as relações de reciprocidade das comunidades de remanescentes de quilombo, nos municípios de Bujaru e Concórdia do Pará, foram construídas baseadas em redes de contato e de trocas, em rituais e em festas que articularam, ao longo do tempo, os vínculos sociais e identitários que se mantém até hoje. 15 Entrevista realizada com o coordenador da festividade, André Barreto, em 25 de novembro de 2018.

16 Entrevista realizada com o coordenador da festividade, André Barreto, em 25 de novembro de 2018.

17 Entrevista realizada com Mirna Dantas, colaboradora que auxilia nos preparativos da festa, em 25 de novembro de 2018.

18 Entrevista realizada com o coordenador da igreja local, Lauro Albuquerque, em 25 de novembro de 2018.

19 Entrevista realizada com o coordenador da igreja local, Lauro Albuquerque, em 25 de novembro de 2018.

\section{Referências:}

ALVES, Isidoro. 1980. O Carnaval Devoto: um estudo sobre a Festa de Nazaré, em Belém. Petrópolis: Editora Vozes.

. 2005. "A festiva devoção no Círio de Nossa Senhora de Nazaré." Estudos Avançados, 19(54):315-332.

CASTRO, Edna. 2003. Quilombolas de Bujaru: memória da escravidão, territorialidade e titulação de terra. Belém: UFPA/NAEA/UNAMAZ. . 2006. Terras de pretos entre rios e igarapés. Belém: Cejup.

COSTA, António. 2011. "Festa de Santo na Cidade: notas sobre uma pesquisa etnográfica na periferia de Belém, Pará, Brasil.” Boletim do Museu paraense Emilio Goeldi, 6(1):197-2016.

CRESWELL, John. 1998. Qualitative Inquiry and Research Design. London: Sage.

DURKHEIM, Émile. 1996. As Formas elementares da vida religiosa: o sistema totêmico na Austrália. São Paulo: Martins Fontes.

FIGUEIREDO, Aldrin. 1995. "Um Natal de Negros: esboço enográfico sobre um ritual religioso num quilombo amazônico." Revista de Antropologia, 38(2):207-238.

GALVÃO, Eduardo. 1955. Santos e visagens: um estudo da vida religiosa de Itá; Amazonas. São Paulo: Companhia Editora Nacional. 1953. "Vida religiosa do caboclo da Amazônia." Boletim do Musen Nacional, (15):1-18. 
GEERTZ, Clifford. 1988. Works and Lives: the anthropologist as author. Cambridge: Polity. . 1989. A Interpretação das Culturas. Rio de Janeiro: Livros Técnicos e Científicos Editora.

MACEDO, C. \& SOUSA, R. 2011. "Comunidades camponesas no nordeste paraense: o caso de São Judas e Cravo.” Revista Geografia (Londrina), 20(2):115-128.

. 2011. "Camponeses e religiosidade na Amazônia Paraense." Revista Terceira Margem, 2(6):41-71.

MALCHER, Maria A. 2011. Territorialidade quilombola no Pará: um estudo da comunidade São Judas, município de Bujaru e da comunidade do Cravo, município de Concórdia do Pará. Dissertação de Mestrado. Belém: Universidade Federal do Pará.

MAUÉS, Raymundo H. 1990. A ilha encantada: medicina e xamanismo numa comunidade de pescadores. Belém: Edufpa.

1995. Padres, pajés, santos e festas: catolicismo popular e controle eclesiástico. Belém: Cejup.

. 2011. "Outra Amazônia: os santos e o catolicismo popular." Norte Ciência, 2(1):1-26.

MAUSS, Marcel. 2003. Sociologia e Antropologia. São Paulo: Cosac \& Naify.

RODRIGUES, Donizete. 2007. Sociologia da Religião: uma introdução. Porto: Edições Afrontamento.

WAGLEY, Charles. 1957. Uma comunidade amazônica: Estudo do homem nos trópicos. São Paulo: Companhia Editora Nacional

\begin{abstract}
Based mainly on Durkheimian theoretical-conceptual construction, this article aims to approach the pilgrimage in honor of Our Lady of Thanks, which takes place, in November, in the quilombola community of Vila do Cravo, Pará. Following the Geertzian methodological orientation, the fieldwork was carried out using participant observation, with dense ethnography, involving symbols, rituals and profane and sacred experiences, lived in the context of the community. This pilgrimage, as a popular religious practice, enables cultural exchanges, (re) meetings and the strengthening of social ties among the pilgrims.
\end{abstract}

Keywords: Ethnography, Círio, Pilgrimage, Our Lady of Thanks, Vila do Cravo/Pará. 